IZA DP No. 2928

Minorities, Social Capital and Voting

Pieter Bevelander

Ravi Pendakur

July 2007 


\title{
Minorities, Social Capital and Voting
}

\author{
Pieter Bevelander \\ IMER, Malmö University \\ and IZA
}

\author{
Ravi Pendakur \\ University of Ottawa
}

\section{Discussion Paper No. 2928 \\ July 2007}

IZA

P.O. Box 7240

53072 Bonn

Germany

Phone: +49-228-3894-0

Fax: +49-228-3894-180

E-mail: iza@iza.org

Any opinions expressed here are those of the author(s) and not those of the institute. Research disseminated by IZA may include views on policy, but the institute itself takes no institutional policy positions.

The Institute for the Study of Labor (IZA) in Bonn is a local and virtual international research center and a place of communication between science, politics and business. IZA is an independent nonprofit company supported by Deutsche Post World Net. The center is associated with the University of Bonn and offers a stimulating research environment through its research networks, research support, and visitors and doctoral programs. IZA engages in (i) original and internationally competitive research in all fields of labor economics, (ii) development of policy concepts, and (iii) dissemination of research results and concepts to the interested public.

IZA Discussion Papers often represent preliminary work and are circulated to encourage discussion. Citation of such a paper should account for its provisional character. A revised version may be available directly from the author. 


\section{ABSTRACT}

\section{Minorities, Social Capital and Voting*}

It is widely held that voter turnout among immigrants and ethnic minorities is lower than among the native born. The goal of our paper is to explore the determinants of voting, comparing immigrant, minority and majority citizens in Canada. We use the 2002 wave of the Equality Security Community Survey to explore the relationship between personal characteristics (age, sex, education, and household type) work characteristics, social capital attributes (trust in government, belonging, civic awareness and interaction with others) and ethnic characteristics (ethnic origin, place of birth and religion) and voting. We find that the combination of socio-demographic and social capital attributes largely overrides the impact of immigration and ethnicity. This suggests that it is not the minority attribute that impacts voting. Rather it is age, level of schooling and level of civic engagement which effects voting, both federal and provincial.

JEL Classification: $\quad$ D72, J15, J61

Keywords: political participation, immigrants, ethnic minorities, voting behaviour, social capital

Corresponding author:

Pieter Bevelander

IMER

Malmö University

20506 Malmö

Sweden

E-mail: pieter.bevelander@imer.mah.se

\footnotetext{
* We wish to thank Uttara Chauhan of Elections Canada for her comments and suggestions and acknowledge the Volkswagen Foundation for its financial support to IZA's Diversity Project.
} 


\section{Minorities, Social Capital and Voting}

\section{Introduction}

One of the core responsibilities in democratic societies is participation in the electoral process. While some countries such as the Netherlands and Sweden allow legally resident non-citizens to vote in local and regional elections this responsibility is restricted to citizens in Canada. Indeed, Canadian citizenship court judges highlight voting as one of the primary benefits of acquiring citizenship.

In settler societies, such as Canada, because citizenship acquisition is relatively rapid the diversity of potential voters has expanded dramatically over the past half century. This fact is recognized by Elections Canada which, through its outreach program, attempts to provide electoral information to potential voters in twenty-six heritage and 11 Aboriginal languages. Despite the interest, however, little is known about the voting probabilities of minorities in Canada. Even less understood is the interaction of voter behaviour with aspects of social capital such as trust, belonging, civic awareness and interaction with others.

In our paper we use the 2002 wave of the Equality Security Community (ESC) survey to measure the odds of voting in the 2000 Federal election and the most recent provincial election prior to 2002. Along with human capital variables such as age and education, we include controls for immigrant status, minority status, as well as social capital variables such as trust in government, sense of belonging and interaction with others (both formal and informal). We are thus able to measure the impact of social capital attributes on the probability of voting controlling for minority status.

We find that formal interaction (membership in organizations and attending religious services) as well as sense of belonging at a local level and civic awareness are strong predictors of voting. Informal interaction (talking to friends and neighbours) does not have a significant effect on the degree to which people vote.

While personal characteristics (age, sex, education, etc) and social capital attributes explain a great deal of voting behaviour, minority status (ethnic origin, immigrant status and language) does not. With few exceptions, after these controls are included in the model, minorities display the same voting probabilities as majority members. 


\section{Determinants of voting behaviour of immigrant and ethnic minorities}

Many studies have tried to identify factors that affect the likelihood and nature of voting behaviour for the population as a whole. However, studies that include an analysis of the voting behaviour of minorities or immigrants are far less frequent in part because of lack of data and in part because immigrants are generally not given voting privileges until after attaining citizenship. This means that there are few studies which look at voting and minority status.

Notable exceptions in the case of European research include Fennema and Tillie (1999) and Togeby (1999). Fennema and Tillie (1999) look at voting by Turks, Moroccans, Surinamese and Antilleans in Amsterdam, focussing in particular on the relationship between voting and trust in institutions. They find that civic engagement and trust in institutions are powerful determinants of voter participation. Togeby examines voting by Turkish immigrants in Denmark arguing that residential concentration and mobilization result in voter participation rates that are as high as for native Danes.

In North America, research on minority voter participation is equally sparse. DeSipio (1996) shows that education and age are powerful correlates of voting (see also Bass and Casper 2001). This is reiterated by Tuckel and Meisel (1994) who look at voting by European minorities living in the United States. They argue that demographic and socioeconomic factors, such as age, education and labour force characteristics are the dominant factors in explaining voting probabilities. Ramakrishnan and Espenshade (2001) use multiple years of the CPS to measure the probability of voting based on minority status. They find that minorities are substantially less likely to vote in elections as compared to native born majority residents. Further, these differences are not always reduced from one generation to another. Bass and Casper (2001) using 1996 CPS data find similar results, concluding that generally age and education are positively correlated with voting as is length of residence for immigrants. Finally Lien (2004) finds that Asians born in the US are less likely to vote than natives.

Ramakrishnan and Espenshade (2001) extend the model of immigrant voting behaviour by adding controls for generation, language proficiency (English), duration of stay, ethnic residential concentration and political socialization in the home country. For generation they find different patterns in voting participation among different racial/ethnic groups. Except for Black and Asia-American immigrants, a longer stay in the US increases the probability of voting. Being an immigrant from a repressive regime has a weak negative effect on voting participation. Language proficiency, as measured by the presence of Spanish-language ballots and proximity to co-ethnics (measured at a state level) did not have a strong effect on the probability of voting. They did find, however that the "political culture" in a state influences voting behaviour.

Cho (1999) uses a 1984 survey of California residents to measure the effect of socioeconomic variables on voting behaviour of four minority groups (Latino, Black, Asian and non-Hispanic white). She argues that socioeconomic variables merely provide the skills for political activity. Socialization determines the degree to which these skills 
are used. Given that immigrant groups in particular have different socialization experiences, their pattern of voting will differ despite having similar socio-demographic characteristics. Thus, while education had little impact for Asian-Americans, it had twice the impact for Latinos. ${ }^{3}$

As suggested earlier, few studies on the determinants of voting behaviour of immigrants and ethnic minorities have been conducted in Canada. ${ }^{4}$ Instead, the focus has been on broader political participation issues such as citizenship acquisition and representation of foreign born in parliament (Bloemraad 2006; DeVoretz and Pivnenko 2006). In another example, Pal and Choudhry (2007) look at the distribution of federal electoral districts, concluding that the visible minority vote is diluted because the system over-represents smaller communities (as compared to larger towns).

Studies looking specifically at voting by minorities are relatively rare. Chui, et al (1991) used the 1984 Canadian Election Survey to measure seven attributes of electoral participation (including voting) using Multiple Classification Analysis. They found that while immigrants did participate less, their offspring either had the same or higher participation rates than was the case for 'deeply rooted Canadians'. A more recent study by Jedwab (2006) uses the 2002 Ethnic Diversity Survey to conduct a tabular analysis of voting by minorities in Canada. He found that increased ethnic belonging and ethnic identity had no negative impact on voting participation and that sense of belonging to Canada correlated with higher voter participation. White et al (2006) using Canadian Election Survey data, found that immigrants in general have similar voting participation rates to the native-born after controlling for education and income. As with Jedwab, they found that years of residence is important in explaining voting behaviour by immigrants.

\section{Extending the model: Social Capital and Voting}

Putnam (1993, 1995, 2000) has argued that civic engagement should be important for a wide variety of issues including political participation. However, while the relationship between human capital and voting is well established, research on the relationship between social capital and voting is still relatively nascent. Several papers have looked at the impact of social capital attributes measured by trust in government and use of media on the probability of voting. In Denmark, for example, Togeby (1999) looks at collective mobilisation as a determinant of voting behaviour. Togeby argues that the Danish local election system creates opportunities for mobilisation through a proportional elections system which incorporates special rules for seat allocation. This in turn results in higher voter participation for immigrants. In Sweden, however, higher concentrations of immigrant groups have led to collective demobilization and rather low voting participation among immigrants (Togeby 1999).

\footnotetext{
${ }^{3}$ A study by Daniel Gordon (1970) looked at voting patterns using aggregate level data from 1934 to 1960 in an attempt to determine the impact of the presence of minorities on the electoral process. Using the size of the immigrant group in each of 198 cities and comparing it to voter turnout, he concluded that the presence of immigrants has a strong impact in cities that have municipal parties, but not in cities that are non-partisan.

${ }^{4}$ Voter turnout for Canadian elections can be found at the following website: http://www.sfu.ca/ aheard/elections/historical-turnout.html
} 
Fennema and Tillie (1999) find civic engagement and social capital to be the most powerful determinants of voter propensities. They argue that if voters have low trust in government this may lead to lower voting participation and when this becomes very low a legitimacy problem comes into play. Theiss-Morse and Hibbing (2005) argue that increased political participation is non-linear with increased political trust and that those with high trust feel less need to participate (see also Claibourn and Martin (2000) and Muhlberger (2003). Others argue, however that participation involves costs. There is thus an incentive to being a free-rider if others can be trusted to make the right political decisions. Nakhaie (2006) used the 2001 National Survey of Giving, Volunteering and Participation to measure the impact of social capital on voter participation in Canada. He found that formal social capital attributes (volunteering, religious participation) as well as 'community rootedness' (belonging) are associated with higher voting probabilities. He was unable, however to test for the impact of minority status.

It appears then, that the jury is still out on whether social capital attributes are important for voter participation. Our study enters the fray by, building on past work to look at human capital and social capital attributes and the probability of voting based on minority status. We treat social capital broadly examining issues of trust, sense of belonging, and civic awareness - reading current events in newspapers and watching the news on television. In addition we assess the extent to which voting is affected by informal and formal contacts. Simply stated the more engaged you are, the more you feel you belong, the more you trust in government and the more formal and informal contacts you have, the more you may be willing to take part in the electoral process.

\section{Data and Method}

\subsection{The Data:}

A major impediment to studies of immigrant voting behaviour is lack of data. Many surveys ask about voting behaviour and many ask about minority status. Few contain both sets of information. Thus, for example, while Chui, et al were able to control for education, age, ethnicity and immigrant status, they were unable to control for issues related to social capital. Our data are drawn from the 2002 wave of the Equality, Community Security Survey. This survey contains a broad range of questions on social capital economic attributes, and voting behaviour as well as detailed demographic characteristics such as ethnic origin and immigrant status. It is particularly useful for studies of ethnicity because the survey includes an oversample of individuals living in census tracts in Montreal, Toronto, and Vancouver with large visible minority populations. Thus, the total number of minorities---defined as people of non-European non-Aboriginal origin---is substantial for a survey of this size. The survey has 5654 respondents, 604 of whom are members of a visible minority. There are 449 immigrant respondents. After selection for citizenship and voting age, we are left with 4,662 respondents, 536 of whom are immigrants. 


\subsection{Variable treatment:}

Along with our variables identifying minority and immigrant status, we include demographic characteristics, socio-economic characteristics and social capital characteristics. The demographic characteristics consist of 4 dummy variable sets: gender (male and female), age (6 dummies), marital status (5 dummies) and presence of children (yes or no). The socioeconomic variables include schooling (8 dummies) and employment status (8 dummies).

We test 10 social capital characteristics which tap different facets of social capital. The first three, measure trust in government and the sense of belonging felt by the respondent. Trust in government (either provincial or federal depending on whether we are testing for federal or provincial voting) is scaled from 1 (trust the government to do the wrong thing most of the time) to 4 (trust the government to do the right thing most of the time). The two sense of belonging questions tap the degree to which the respondent feels he or she belongs at a national level and a neighbourhood level. The two variables are scaled from 1 to 10 , where 1 means the respondent does not feel he belongs and 10 means the respondent feels he belongs completely.

The next two variables tap civic awareness using questions that ask about the frequency of either reading about local news in the paper or watching the news on television. Awareness is measured on a seven point scale where 1 means the respondent never reads or watches the news and 7 means that the respondent reads or watches the news ever day.

The next two variables tap informal interaction with either friends or family and are scaled from 1 to 7 . The last three variables tap formal interaction. Frequency of attendance at religious services (scaled from 1-7) membership in voluntary organizations (dichotomous) and membership in organized recreational groups (dichotomous) measure the degree to which the respondent is involved in formal, organized interaction with others.

Minority status variables include age at immigration (6 dummy variables), language spoken at home (either English/French or other), and ethnic origin. Ethnicity is divided into 3 broad categories: British/French/Canadian, European origins and visible minority origins.

\section{$4 \quad$ Analysis}

Our analysis is divided into two main parts. The first explores the issue using descriptive statistics on voting behaviour. The second tests three models using probit regressions to measure the odds of voting in the federal and provincial election.

\subsection{Descriptive results: Basic findings for voting participation}

The descriptive statistics in table 1a in the appendix provide an initial picture of the differences in voting participation according to both the demographic, socio-economic, 
ethnicity and social capital variables included in the model. The discussion however, will primarily be on the different ethnicity and social capital variables including: trust in government, sense of belonging, either to Canada or the province, or to the neighbourhood, current affairs awareness by frequency of reading the newspaper or watching the news on television, informal interaction like seeing friends or talk to neighbours and finally formal interaction through religious attendance, member of voluntary organisation and member of recreational organisation.

In the table of descriptives, we see a curvilinear relationship between trust in government and voting behaviour in both the federal or provincial elections. Those who almost never trust government are less likely to vote than those who have some trust. Those that trust most of the time have an even higher voting rate. However those that almost always trust government to do the right thing most of the time have a lower rate of voting participation than those with lower levels of trust.

A higher sense of belonging correlates with increasing voting participation at both the federal and provincial level. This is especially true for belonging at the neighbourhood level where the difference between those that do not feel they belong in the neighbourhood and those that do is 26 per cent. Voting participation is also positively correlated with current affairs awareness. The more one reads the paper or watches the news on television, the more likely it is that they will vote.

Informal interaction is measured by seeing friends and talking to neighbours. The descriptive statistics in Table 1a suggest that those who never see friends or talk to neighbours have a lower rate of voting both federally and provincially. However those who do see friends or talk to neighbours, regardless of frequency, do display higher rates of voting.

Formal interaction is measured by responses to three questions: attending religious services, being a member of a voluntary group or being a member of an organized recreational group. Attending religious services is positively correlated with voting. The more one attends religious services, the higher the likelihood of voting. Both being a voluntary member of an organisation and being a member of a recreational group also yields higher voting participation in both provincial and federal elections. This result is in line with earlier studies that suggest individuals that higher degrees of social activity have a higher political participation, including voting (Egmond van, de Graaf andvan der Eijk (1998).

Ethnocultural origin is tapped through variables asking about immigrant status, age at immigration, home language, religion and ethnic origin. From the table it is clear that individuals born in Canada are more likely to vote than immigrants. This is particularly true for immigrants who arrived in Canada when they were young. Immigrants who arrived before the age of 15, are less likely to vote that those who arrived later in life. Respondents claiming no religion and those claiming Islam as a religion have a lower voting participation rate as compared to people claiming other religions. Christians have a higher rate of voting. Speaking English or French at home (as compared to another 
language) is also correlated with higher voter participation. This is in line with what Cho (1999) finds for the US. Finally, the table shows that individuals who consider themselves to be part of a majority ethnic origin and those with European backgrounds have a higher voting participation rate than those that consider themselves to be members of a visible minority.

A more detailed ethnic group categorisation shows that individuals with Chinese and East and Southeast Asian background have a lower voting participation rate. Also black individuals and aboriginals vote less compared to other ethnic groups. ${ }^{5}$ These results accord with the finding of Ramakrishnan and Espenshade (2001).

\subsection{Probits}

Overall, analysis of the descriptive statistics suggests that with the exception of seeing friends, social capital, both formal and informal has a positive impact on voter participation. Social background, based on religion, ethnic origin and immigrant status also has an impact. However in this case, membership in a minority group is associated with lower voter participation rates. In our next section we run three sets of probit regressions ${ }^{6}$ (table 1-3) in order to measure the odds of voting in the 2002 federal or provincial election in order to test the combined effect of these attributes. The first model includes only demographic and socio-economic characteristics (not including ethnic and immigrant characteristics). The second model adds the ten social capital variables and the third model interacts the social capital variables with membership in the ethnic categories. The social capital variables that are scaled (trust, belonging, civic awareness and religious attendance) are standardized so that the strength of the variables is directly comparable.

\section{Table 1 about here}

\subsubsection{Model 1: Demographics and socio-economic variables}

Previous research has suggested that age and schooling are powerful predictors in determining the degree to which people vote (see DeSipio 1996; Bass and Casper 2001; and Tuckel and Meisel 1994). Our analysis seconds these findings. We find that older age groups are far more likely to vote as compared to younger age groups. The odds of voting for people in their sixties are roughly 3.5 times that of people who are less than 30 years old. People who are married are more likely to vote, as compared to those who are living alone; however having children has no impact on voting patterns. Gender has no impact on the odds of voting.

\footnotetext{
${ }^{5}$ Note that while we conducted tests with a more detailed ethnic origin legend, this paper concentrates on the findings using relatively broad ethnic categorizations. This is because we are specifically interested in the interactions between social capital and ethnicity, and this is not possible with a highly detailed list of ethnic origins.

${ }^{6}$ Wave II of the ESC does not include a weighting variable, however we have added information about the sample design (province, and the oversample information for Montreal, Toronto and Vancouver) to the model using Stata's survey set criteria. .
} 
As was seen in previous work, education has a strong positive effect. People with a BA have about twice the odds of voting compared to people who have less than high school. Working for pay increases the odds of voting as compared to being self-employed by about one-fifth for federal elections, but has no impact for provincial elections. Being disabled, decreases the odds of voting by about half in federal elections and students have lower odds of voting in provincial elections compared to other types of economic activity, however other forms of activity have no significant effect on voting behaviour. We note that the demographic and socio-economic coefficients are remarkably stable from one regression to another, maintaining roughly the same direction, magnitude and significance from one model to another.

\section{Table 2 about here}

\subsubsection{Model 2: Social Capital}

Model 2 adds the ten standarized social capital variables to the analysis. Looking first the results for the federal election we see that five of the 8 standardized variables have significant positive effects. The most powerful effects are religious attendance (1.14), and belonging at the neighbourhood level (1.10). Trust in the federal government, and current affairs awareness (reading and watching the news regularly) also have positive effects (ranging from 1.07 to 1.09). However belonging at the Canada level, seeing friends and talking to neighbours has no impact on voting. Volunteering has no effect on voting federally; however being a member of a recreational group does have an effect (1.15).

Results for voting in provincial elections display some interesting differences. Trust in government, watching the news, attending religious services and being a member of a recreational group has about the same impact on voting as was seen federally. Sense of belonging at a Canada level, has a strong and significant negative impact on provincial voting (0.94 for every standard deviation increase). Being a volunteer has a strong positive impact (1.18).

Overall this suggests that formal organized interaction such as taking part in voluntary organizations, membership in recreational groups and attending religious services has a positive impact on voting. Respondents who attend religious services weekly display more than double the odds of voting in a federal election compared to people who do not attend religious services. However informal interaction such as see friends and talking to neighbours has no impact on voting. Sense of belonging in the neighbourhood has a positive impact on voting, but sense of belonging at a national level has either no impact (federally) or a negative impact (nationally). With few exceptions, this is true for both federal and provincial voting.

Table 3 about here 


\subsubsection{Models 3: Ethnicity, Religion}

Model 3 adds controls for immigration and religion and includes interactions between ethnicity and the social capital variables. Looking first at the results for the federal election we see that as compared to people who claim no religion, Protestants, and those in the 'Other Judeo-Christian' group are more likely to vote (the odds increase by 1.21 and 1.59 respectively). However Evangelical Protestants, Catholics, Muslims and Sikhs and Hindus (other eastern) have about the same odds of voting as people claiming no religion. Immigrants who arrive in their 20s have lower odds of voting federally, but other immigrant groups have about the same odds of voting as people born in Canada.

The effects of the social capital variables are similar to those seen model 2, however there are some interaction effects by ethnic origin. Specifically, watching the news has a positive effect, however the interaction terms with ethnic origin display lower odds of voting. Thus the interaction of European and watching the news has a significant coefficient of .89 and the interaction with visible minority has a significant coefficient of .82. This suggests that minorities who watch the news reap a lower 'voting benefit' compared to majority members who watch the news. The only other significant interaction is with recreational activity and European. While recreational activity has a positive impact on the odds of voting (1.22) being European and being involved in recreational activity displays lower odds of voting (.67).

Much of the impact of religiosity is picked up in the variable that measures attendance at religious ceremonies. As with the previous model, the more frequent the attendance, the more likely the person is to vote. However there is no additional impact by ethnic origin. Rather it appears that it is the attendance that matters, not the religion or the ethnic origin of the respondent.

Results for voting provincially are similar in spirit with the social capital variables that were significant in model 2 maintaining roughly the same magnitude and significance. With the exception of one variable, there are no significant interaction effects. Trust in the provincial government interacted with ethnicity lowers the odds of voting compared to majority members (.89 for Europeans and .80 for visible minorities).

\section{Concluding discussion}

In this paper we examine the voting behaviour of immigrants and ethnic minorities in Canada using the 2002 wave of the Equality Security Community (ESC) survey. Using probit regression techniques, we measure the odds of voting in the 2000 Federal election and the most recent provincial election prior to 2001. We find that overall, there are few differences between majority and minority members and their odds of voting after socioeconomic and social capital attributes have been included in the model. In other words, it is not minority status driving voter turnout. Rather it is largely the demographic, socioeconomic and social capital attributes that explain voter turnout. 
As with Bass and Casper (2001), Tuckel and Meisel (1994) and White et al. (2006) we found that increased age and higher education have a strong positive effect on voting behaviour. Moreover, married individuals have a higher voting probability as do those who work for pay. Gender did not have a significant impact on voting.

After controlling for social capital and socio-economic attributes, we did not find any significant differences by ethnic origin. This is similar to that found by Jedwab (2006) but counter to Ramakrishnan and Espanshade (2001). However as with Chui, et al, we found that immigrants who arrived in their 20s or 40s were less likely to vote than those who arrived at an earlier age, or those who were born in Canada.

Overall, religious affiliation does not make a difference in voting. Only Protestants displayed higher odds of voting, as compared to people claiming no religion. Rather it is the formal activity of attendance at religious services that increases voter turnout.

Probit regressions revealed that with the exception of informal interaction, social capital attributes were powerful determinants of voter turnout. A high sense of belonging at a local (neighbourhood) level increased the odds of voting in both provincial and federal elections. However, in contrast to Jedwab (2006) we found that belonging at the national level, has no impact on federal voting. Indeed, a high sense of belonging at the provincial level decreases the odds of voting in a provincial election.

Trust in government (whether provincial or federal) is important. As compared to Theiss-Morse and Hibbing (2005) we found that higher levels of trust corresponded to higher voter participation. Related to this, awareness of issues (either through reading or watching the news) is also correlated with higher voter turnout.

The impact of formal and informal activity on voting depends on the activity itself. Bonding activity, such as talking to friends and neighbours has no impact on voter turnout. However, attending religious services, a broadly bonding activity, has a strong positive impact on voting. Being a member of a recreational group, which is potentially a bridging activity, is associated with higher odds of voting in both federal and provincial elections. However voluntarism, another potentially bridging activity is only associated with higher odds of voting at the provincial level.

In conclusion, it appears that social capital matters for voting. High levels of formal interaction, trust and belonging are clearly associated with higher odds of voting. Indeed, the combination of socio-demographic and social capital attributes largely overrides the impact of immigration and ethnicity, suggesting that it is not the minority attribute that impacts voting. Rather it is age, level of schooling and level of civic engagement which effects voting, both federal and provincial. 


\section{References}

Bass, L. E. andCasper, L.M. (2001) “Impacting the Political Landscape: Who Registers and Votes among Naturalized Americans?”, Political Behavior, Vol. 23, No. 2, pp. 103-130.

Bloemraad, I. (2006) Becoming a Citizen, Incorporating Immigrants and Refugees in the United States and Canada, Berkeley: University of California press.

Cho, Tam. (1999) “Naturalization, Socialization, Participation: Immigrants and (Non-) Voting”, The Journal of Politics, Vol. 61, No. 4, pp. 1140-1155.

Chui, T. , J Curtis and R Lambert. (1991) "Immigrant background and political participation: examining generational patterns” Canadian Jourrnal of Sociology vol 16(4), pp. 375-396.

DeVoretz, D. andPivnenko, Sergiy. (2006) “The Economic Causes and Consequences of Canadian Citizenship” Journal of International Migration and Integration, Vol. 6. 3/4, pp. 435-468.

DeSipio, L. (1996) “Making citizens or good citizens? Naturalization as predictor of organizational and political behavior among Latino immigrants” Hispanic Journal of Behavior Sciences, Vol. 18, pp. 195-213.

Diehl, C. andBlohm, M. (2001) “Apathy, adaptation or ethnic mobilization? On the attitudes of a politically excluded group”, Journal of Ethnic and Migration Studies, Vol. 27, No. 3, pp. 401-420.

Egmond van M, de Graaf N. D. andvan der Eijk, C. (1998) "Electoral participation in the Netherlands: Individual and contextual influences”, European Journal of Political Research, Vol. 34: 281-300.

Fennema, M. andTillie, J. (1999) "Political participation and political trust in Amsterdam: civic communities and ethnic networks" Journal of Ethnic and Migration Studies, Vol. 25 No. 4, pp. 703-726.

Gordon, D. (1970) "Immigrants and municipal voting turnout: implications for the changing ethnic impact on urban politics,” American Sociological Review, Vol. 35(4). pp. 665-681.

Jedwab, J. (2006) “The "Roots" of Immigrant and Ethnic Voter Participation in Canada" in Electoral Insight, Electoral Participation of Ethnocultural Communities, Vol. 8, No. 2. 
Lien, Pei-te. (2004) "Asian Americans and Voting Participation: Comparing Racial and Ethnic Differences in Recent U.S. Elections”, International Migration Review, Vol. 38, No. 2, pp. 493-517.

Nakhaie, R. (2006) "Electoral Participation in Municipal, Provincial and Federal Elections in Canada.” Canadian Journal of Political Science vol 39(2). Pp. 363390.

Pal, M. andChoudhry, S. (2007) "Is Every Ballot Equal? Visible-Minority Vote Dilution in Canada" IRPP Choices, Vol. 13, No 1.

Putnam, R. D. (1993) Making Democracy Work: Civic Traditions in Modern Italy, Princeton: Princeton University press.

Putnam, R. D. (1995) “Bowling Alone, America’s declining Social Capital”, The Journal of Democracy, 6:1, pages 65-78.

Putnam, R. D. (2000) Bowling alone: The collapse and Revival of American Community. New York: Simon andSchuster.

Ramakrishnan, S. K. and T. Espenshade. (2001) "Immigrant Incorporation and Political Participation in the United States” International Migration Review, Vol. 35, No. 3, pp. 870-909.

Togeby, L. (1999) "Migrants at the polls: an analysis of immigrant and refugee participation in Danish local elections" Journal of Ethnic and Migration Studies, Vol. 25 No. 4. pp. 665-684.

Tuckel, P. andMaisel, R. (1994) "Voter Turnout among Europeans Immigrants to the United states", Journal of Interdisciplinary History, Vol. 24, No. 3, pp. 407-430.

White, S. et al (2006) "Making Up for Lost Time, Immigrant Voter Turnout in Canada" in Electoral Insight, Electoral Participation of Ethnocultural Communities, Vol. 8, No. 2. 


\section{Appendix}

This appendix describes the variables used in the analysis and the basic descriptive statistics.

Voting (dependent variable):

Did you vote in the last FEDERAL election in 2000?

1 yes 5 no d don't know $r$ refused

Did you vote in the last Provincial election?

1 yes 5 no d don't know $r$ refused

Respondent's gender:

Male

Female

Age:

In what year were you born?

\section{Marital Status:}

Are you presently:

married

living with a partner

separated

divorced

widowed

never been married

Presence of Children:

How many children live with you (Does this child currently live with you) for four or more days a week?

no/none

yes/1-12 children

What is the highest level of education that you have completed?

Lower or Some elementary school

Some secondary

High school

Some technical, community college, CEGEP, College Classique

Completed technical, community college, CEGEP, College Classique 
Some university (includes obtained certificate but not a degree)

Bachelor's Degree

Master's degree / Doctorate

\section{Economic Status:}

Are you currently self employed, working for pay, retired, unemployed or looking for work, a student, a homemaker, or something else?

self employed (with or without employees)

working for pay (full or part time )

retired

unemployed/looking for work

student

homemaker

disabled

Immigrant Status:

Age at Immigration (calculated from age and year of immigration)

\section{Citizenship (Selection variable)}

Are you a Canadian Citizen?

yes or no

\section{Broad Ethnicity}

To what ethnic or cultural group do you belong?

Recoded to British/French/Canadian; European; Visible Minority

Home language at home

What language do you usually speak at home?

English/French

other

\section{Religion:}

Please tell me what is your religion, if you have one?

Recoded to:

None, Protestant; Evangelical Protestant; Catholic; Other Judeo-Christian;

Muslim; Other Eastern; Other. 
Contact Friends and Neighbours:

How often do you see close friends?

And how often do you talk with neighbours?

1 every day

2 several times a week

3 at least once a week

4 at least once a month

5 several times a year

6 less often (includes never)

0 no close friends

Trust in Government:

How much do you trust the government in Ottawa to do what is right?

How much do you trust the government in [R's PROVINCE] to do what is right?

1 almost always (includes always)

3 most of the time

5 some of the time

7 almost never (includes never)

Member of a voluntary organization (1 if yes to any of the following):

I am going to read a list of different types of groups and organizations. For each of them, I would like you to tell me how many groups of that type, if any, you are a member of...

How many service clubs, such as the Lions Club or Meals on Wheels, do you belong to?

How many organizations active on political issues, such as the environment or taxpayers' rights, do you belong to?

How many youth-oriented groups, such as Girl Guides or Minor Hockey, have you volunteered time to in the last 12 months?

How about organizations providing cultural services to the public, such as a museum or music festival.

How about organizations that help people, such as the Cancer Society or a food bank?

How many organizations connected with your own nationality or ethnic or racial group are you a member of?

How many groups directly associated with your place of worship, such as a charitable group, are you a member of?

Do you belong to or volunteer for any other groups or organizations that we have NOT asked about?

Recreational member (1 if greater than 0 )

How many recreational groups, such as sports leagues or clubs, music or hobby clubs, or exercise classes are you involved in? 
Current affairs awareness:

In a typical week, how many days do you read a daily newspaper / watch the news on television?

0 none 1-7 code number of days

\section{Belonging:}

Please tell me how much you feel that you belong to each of the following places. Using a scale from 1 to 10 where 1 means you feel like you do not belong at all and 10 means you feel that you belong completely, what number best describes how you feel about Canada? Province? Neighbourhood? 1-10 enter number

Attendance at religious services

How often do you attend religious services, not including weddings and funerals? nearly every week (includes every week or more often)

2-3 times a month about once a month several times a year once or twice a year less than once a year never 


\begin{tabular}{|c|c|c|c|c|c|}
\hline \multicolumn{6}{|c|}{\begin{tabular}{|l|l|l|l|l|} 
Table 1a & & & & \\
\end{tabular}} \\
\hline \multicolumn{6}{|c|}{$\begin{array}{l}\text { Descriptive Statistics showing the percentage of respondents who say they voted in the } 2002 \text { federal election, } \\
\text { or the last provincial election prior to } 2002\end{array}$} \\
\hline & & & Federally & Provincially & count \\
\hline Total & & & $82 \%$ & $77 \%$ & 4888 \\
\hline \multirow[t]{15}{*}{ Demographic } & Sex & Female & $82 \%$ & $77 \%$ & 2658 \\
\hline & & Male & $82 \%$ & $77 \%$ & 2230 \\
\hline & Age & $21-29$ & $61 \%$ & $52 \%$ & 770 \\
\hline & & $30-39$ & $78 \%$ & $74 \%$ & 987 \\
\hline & & $40-49$ & $86 \%$ & $81 \%$ & 1231 \\
\hline & & $50-59$ & $86 \%$ & $84 \%$ & 836 \\
\hline & & $60-69$ & $93 \%$ & $91 \%$ & 507 \\
\hline & & $70+$ & $92 \%$ & $88 \%$ & 557 \\
\hline & Marital Status & married & $85 \%$ & $81 \%$ & 2939 \\
\hline & & separated & $79 \%$ & $75 \%$ & 182 \\
\hline & & divorced & $82 \%$ & $77 \%$ & 373 \\
\hline & & widow & $89 \%$ & $82 \%$ & 361 \\
\hline & & single & $69 \%$ & $65 \%$ & 1016 \\
\hline & Kids in House & no kids & $81 \%$ & $77 \%$ & 2992 \\
\hline & & Kids & $83 \%$ & $78 \%$ & 1896 \\
\hline \multirow[t]{15}{*}{ Socio-economic } & $\begin{array}{l}\text { Highest level of } \\
\text { schooling }\end{array}$ & <=elementary & $82 \%$ & $79 \%$ & 218 \\
\hline & & some 2ndardy & $79 \%$ & $75 \%$ & 575 \\
\hline & & Highschool & $78 \%$ & $75 \%$ & 1033 \\
\hline & & some tech & $79 \%$ & $75 \%$ & 337 \\
\hline & & technical & $79 \%$ & $74 \%$ & 894 \\
\hline & & some univ & $84 \%$ & $77 \%$ & 403 \\
\hline & & BA & $85 \%$ & $81 \%$ & 971 \\
\hline & & MA/PhD & $91 \%$ & $86 \%$ & 373 \\
\hline & Employment Status & $\begin{array}{l}\text { self employed } \\
\text { (with o }\end{array}$ & $81 \%$ & $79 \%$ & 566 \\
\hline & & $\begin{array}{l}\text { working for } \\
\text { pay (full }\end{array}$ & $82 \%$ & $76 \%$ & 2447 \\
\hline & & retired & $91 \%$ & $89 \%$ & 992 \\
\hline & & $\begin{array}{l}\text { unemployed/lo } \\
\text { oking fo }\end{array}$ & $72 \%$ & $70 \%$ & 251 \\
\hline & & student & $59 \%$ & $44 \%$ & 195 \\
\hline & & homemaker & $77 \%$ & $74 \%$ & 244 \\
\hline & & disabled & $65 \%$ & $68 \%$ & 62 \\
\hline \multirow[t]{13}{*}{ Ethnicity } & Age at immigration & $\begin{array}{l}\text { born in } \\
\text { Canada }\end{array}$ & $82 \%$ & $78 \%$ & 4352 \\
\hline & & It 15 & $73 \%$ & $67 \%$ & 154 \\
\hline & & $15-19$ & $80 \%$ & $76 \%$ & 54 \\
\hline & & $20-29$ & $80 \%$ & $72 \%$ & 200 \\
\hline & & $30-39$ & $80 \%$ & $76 \%$ & 94 \\
\hline & & $40+$ & $79 \%$ & $68 \%$ & 34 \\
\hline & Home language & $\begin{array}{l}\text { English or } \\
\text { french }\end{array}$ & $83 \%$ & $78 \%$ & 4524 \\
\hline & & other & $73 \%$ & $64 \%$ & 364 \\
\hline & Religion & none & $73 \%$ & $70 \%$ & 896 \\
\hline & & protestant & $88 \%$ & $82 \%$ & 1295 \\
\hline & & evangelical & $78 \%$ & $72 \%$ & 439 \\
\hline & & Catholic & $84 \%$ & $79 \%$ & 1774 \\
\hline & & oth judeochrist & $85 \%$ & $80 \%$ & 130 \\
\hline
\end{tabular}




\begin{tabular}{|c|c|c|c|c|c|}
\hline & & muslim & $72 \%$ & $65 \%$ & 72 \\
\hline & & oth eastern & $78 \%$ & $70 \%$ & 87 \\
\hline & & other & $74 \%$ & $71 \%$ & 126 \\
\hline & Ethnic origin & Majority & $84 \%$ & 79\% & 3204 \\
\hline & & European & $81 \%$ & $77 \%$ & 1029 \\
\hline & & Vismin & $71 \%$ & $66 \%$ & 369 \\
\hline \multirow[t]{4}{*}{ Trust } & Trust government & 1 & $79 \%$ & $73 \%$ & 1056 \\
\hline & & 2 & $82 \%$ & $79 \%$ & 2257 \\
\hline & & 3 & $85 \%$ & $79 \%$ & 1203 \\
\hline & & 4 & $80 \%$ & $75 \%$ & 265 \\
\hline \multirow[t]{20}{*}{ Belonging } & Belonging: Canada & $\begin{array}{l}\text { feel like do not } \\
\text { belong }\end{array}$ & $73 \%$ & $75 \%$ & 59 \\
\hline & & 2 & $71 \%$ & $80 \%$ & 51 \\
\hline & & 3 & $85 \%$ & $81 \%$ & 27 \\
\hline & & 4 & $80 \%$ & $73 \%$ & 56 \\
\hline & & 5 & $79 \%$ & $77 \%$ & 201 \\
\hline & & 6 & $71 \%$ & $70 \%$ & 167 \\
\hline & & 7 & $80 \%$ & $73 \%$ & 362 \\
\hline & & 8 & $79 \%$ & $76 \%$ & 742 \\
\hline & & 9 & $78 \%$ & $75 \%$ & 499 \\
\hline & & $\begin{array}{l}\text { feel like belong } \\
\text { completely }\end{array}$ & $85 \%$ & $79 \%$ & 2691 \\
\hline & $\begin{array}{l}\text { Belonging: } \\
\text { neighbourhood }\end{array}$ & $\begin{array}{l}\text { feel like do not } \\
\text { belong }\end{array}$ & $60 \%$ & $62 \%$ & 63 \\
\hline & & 2 & $75 \%$ & $67 \%$ & 63 \\
\hline & & 3 & $64 \%$ & $56 \%$ & 66 \\
\hline & & 4 & $67 \%$ & $61 \%$ & 67 \\
\hline & & 5 & $72 \%$ & $62 \%$ & 314 \\
\hline & & 6 & $78 \%$ & $71 \%$ & 252 \\
\hline & & 7 & $79 \%$ & $73 \%$ & 470 \\
\hline & & 8 & $82 \%$ & $75 \%$ & 898 \\
\hline & & 9 & $84 \%$ & $80 \%$ & 532 \\
\hline & & $\begin{array}{l}\text { feel like belong } \\
\text { completely }\end{array}$ & $86 \%$ & $83 \%$ & 2115 \\
\hline \multirow{16}{*}{$\begin{array}{l}\text { Current affairs } \\
\text { awareness }\end{array}$} & Read the news & never & $75 \%$ & $71 \%$ & 836 \\
\hline & & 1 day a week & $79 \%$ & $73 \%$ & 844 \\
\hline & & 2 & $78 \%$ & $74 \%$ & 490 \\
\hline & & 3 & $77 \%$ & $74 \%$ & 410 \\
\hline & & 4 & $82 \%$ & $76 \%$ & 200 \\
\hline & & 5 & $81 \%$ & $72 \%$ & 358 \\
\hline & & 6 & $90 \%$ & $87 \%$ & 420 \\
\hline & & 7 days a week & $89 \%$ & $84 \%$ & 1305 \\
\hline & Watch the news & never & $71 \%$ & $66 \%$ & 365 \\
\hline & & 1 day a week & $71 \%$ & $66 \%$ & 289 \\
\hline & & 2 & $77 \%$ & $71 \%$ & 346 \\
\hline & & 3 & $78 \%$ & $72 \%$ & 344 \\
\hline & & 4 & $83 \%$ & $76 \%$ & 333 \\
\hline & & 5 & $82 \%$ & $78 \%$ & 658 \\
\hline & & 6 & $87 \%$ & $87 \%$ & 218 \\
\hline & & 7 days a week & $85 \%$ & $81 \%$ & 2318 \\
\hline \multirow[t]{8}{*}{ informal interaction } & See friends & never & $76 \%$ & $67 \%$ & 221 \\
\hline & & yearly & $84 \%$ & $79 \%$ & 264 \\
\hline & & monthly & $81 \%$ & $77 \%$ & 826 \\
\hline & & weekly & $84 \%$ & $80 \%$ & 1624 \\
\hline & & biweekly & $81 \%$ & $77 \%$ & 1157 \\
\hline & & daily & $79 \%$ & $74 \%$ & 796 \\
\hline & Talk to neighbours & never & $71 \%$ & $63 \%$ & 553 \\
\hline & & yearly & $81 \%$ & $75 \%$ & 315 \\
\hline
\end{tabular}




\begin{tabular}{|c|c|c|c|c|c|}
\hline & & monthly & $82 \%$ & $75 \%$ & 830 \\
\hline & & weekly & $84 \%$ & $78 \%$ & 1255 \\
\hline & & biweekly & $84 \%$ & $83 \%$ & 978 \\
\hline & & daily & $84 \%$ & $80 \%$ & 957 \\
\hline \multirow[t]{11}{*}{ Formal interaction } & Attend religious services & never & $74 \%$ & $70 \%$ & 1509 \\
\hline & & annual & $83 \%$ & $74 \%$ & 321 \\
\hline & & biannual & $82 \%$ & $74 \%$ & 704 \\
\hline & & triannual & $85 \%$ & $81 \%$ & 520 \\
\hline & & month & $85 \%$ & $81 \%$ & 336 \\
\hline & & bimonth & $88 \%$ & $81 \%$ & 354 \\
\hline & & weekly & $88 \%$ & $85 \%$ & 1144 \\
\hline & Member: voluntary org & not a member & $77 \%$ & $70 \%$ & 1429 \\
\hline & & member & $84 \%$ & $80 \%$ & 3459 \\
\hline & $\begin{array}{l}\text { Member: recreational } \\
\text { group }\end{array}$ & not a member & $79 \%$ & $75 \%$ & 2495 \\
\hline & & member & $84 \%$ & $80 \%$ & 2393 \\
\hline
\end{tabular}




\begin{tabular}{|c|c|c|c|c|c|c|}
\hline Table 1 & & & & & & \\
\hline $\begin{array}{l}\text { Results from pr } \\
\text { election by pers }\end{array}$ & $\begin{array}{l}\text { bit regressions } \\
\text { onal and socio- }\end{array}$ & $\begin{array}{l}\text { lowing the odds of } \\
\text { onomic characteris }\end{array}$ & $\begin{array}{l}\text { loting in a } f \\
\text { cs }\end{array}$ & edera & or provincial & \\
\hline & & & & & & \\
\hline & & & federal & & provincial & \\
\hline & & & $\begin{array}{l}\text { Odds } \\
\text { ratio }\end{array}$ & sig & Odds ratio & sig \\
\hline & & observations & 4662,00 & & 4662,00 & \\
\hline Demographic & Sex (Female) & Male & 0,99 & & 1,01 & \\
\hline & Age & $30-39$ & 1,54 & *** & 1,60 & *** \\
\hline & $(21-29)$ & $40-49$ & 2,06 & $* * *$ & 2,09 & $* * *$ \\
\hline & & $50-59$ & 2,31 & $* * *$ & 2,49 & $* * *$ \\
\hline & & $60-69$ & 3,89 & $* * *$ & 3,70 & *** \\
\hline & & $70+$ & 3,71 & $* * *$ & 3,43 & $* * *$ \\
\hline & Marital Status & Single & 0,73 & $\star * *$ & 0,77 & ** \\
\hline & (Married) & Separated & 0,76 & $* * *$ & 0,73 & $\star * *$ \\
\hline & & Divorced & 0,83 & $*$ & 0,67 & $* * *$ \\
\hline & & Widowed & 0,79 & $* * *$ & 0,87 & ** \\
\hline & $\begin{array}{l}\text { Presence of } \\
\text { Children }\end{array}$ & with kids & 1,04 & & 1,04 & \\
\hline Socio-economic & Schooling & Some secondary & 1,15 & & 1,09 & \\
\hline & (< Secondary) & Highschool & 1,26 & ** & 1,22 & ${ }^{*}$ \\
\hline & & Some technical & 1,42 & $\star * *$ & 1,37 & ** \\
\hline & & Tech cert. & 1,48 & $* * *$ & 1,36 & ** \\
\hline & & Some univ. & 1,90 & *** & 1,55 & *** \\
\hline & & BA & 1,95 & $\star * *$ & 1,77 & *** \\
\hline & & MA/PhD & 2,34 & $* * *$ & 1,91 & $* * *$ \\
\hline & $\begin{array}{l}\text { Employment } \\
\text { Status }\end{array}$ & Working for pay & 1,22 & $* * *$ & 1,06 & \\
\hline & (Self-employed) & Retired & 1,09 & & 1,18 & \\
\hline & & Unemployed & 1,01 & & 1,04 & \\
\hline & & Student & 0,95 & & 0,71 & $* * *$ \\
\hline & & Homemaker & 0,94 & & 0,96 & \\
\hline & & $\begin{array}{l}\text { Disabled (can't } \\
\text { work) }\end{array}$ & 0,64 & ** & 0,76 & \\
\hline Significance: *: & 0.1 level; **: 0.05 & vel; ***: 0.01 level & & & & \\
\hline
\end{tabular}




\begin{tabular}{|c|c|c|c|c|c|}
\hline \multicolumn{6}{|c|}{\begin{tabular}{|l|l|l|l|l|l|} 
Table 2 & & & & & \\
\end{tabular}} \\
\hline \multicolumn{6}{|c|}{$\begin{array}{l}\text { Selected results from probit regressions showing the odds of voting by social capital } \\
\text { attributes, controlling for personal characteristics, and socio-economic characteristics }\end{array}$} \\
\hline & & & & & \\
\hline & & federal & & provincial & \\
\hline & & Odds ratio & sig & Odds ratio & sig \\
\hline & observations & 4490,00 & & 4490,00 & \\
\hline \multirow[t]{8}{*}{ Standardized } & Trust federal govt & 1,07 & **k & 1,05 & ** \\
\hline & Belonging: Canada & 1,04 & & 0,94 & ** \\
\hline & $\begin{array}{l}\text { Belonging: } \\
\text { neighbourhood }\end{array}$ & 1,10 & *** & 1,16 & *** \\
\hline & Read news & 1,09 & *** & 1,04 & \\
\hline & Watch news & 1,07 & $* \star \star$ & 1,08 & $* \star *$ \\
\hline & See friends & 1,00 & & 1,01 & \\
\hline & See neighbours & 1,01 & & 0,98 & \\
\hline & $\begin{array}{l}\text { Attend religious } \\
\text { services }\end{array}$ & 1,14 & $* * *$ & 1,11 & *** \\
\hline Don't volunteer & Volunteer & 1,08 & & 1,18 & *** \\
\hline Not a member & Recreation org & 1,15 & $* * \star$ & 1,13 & *** \\
\hline \multicolumn{2}{|c|}{$\begin{array}{l}\text { Significance: *: } 0.1 \text { level; **: } 0.05 \text { level; *** } \\
0.01 \text { level }\end{array}$} & & & & \\
\hline
\end{tabular}


Table 3

Selected results from probit regressions showing the odds of voting by origin and social capital attributes, controlling for personal characteristics, and socio-economic characteristics

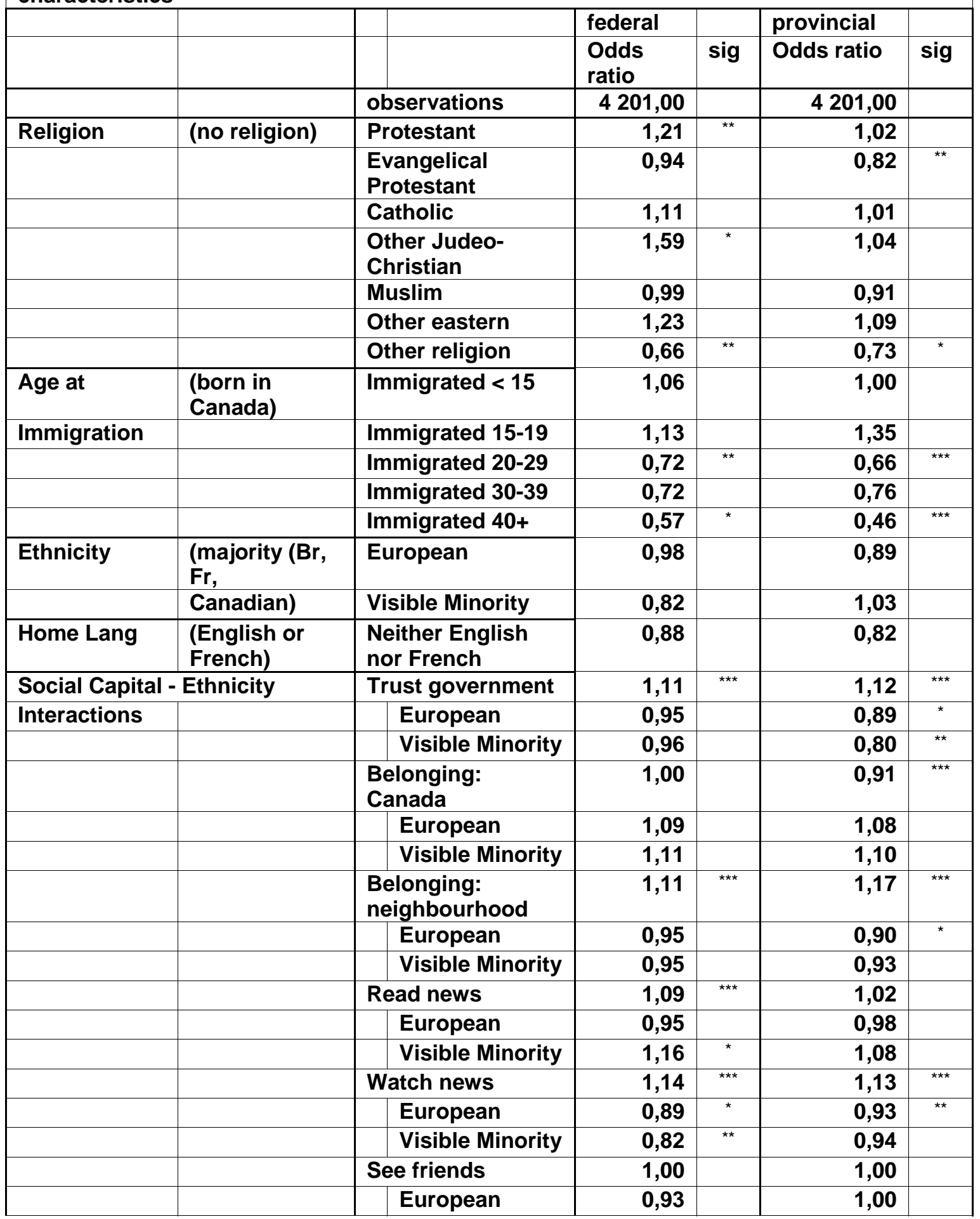




\begin{tabular}{|c|c|c|c|c|c|c|}
\hline & & Visible Minority & 0,88 & & 0,96 & \\
\hline & & See neighbours & 1,01 & & 1,01 & \\
\hline & & \begin{tabular}{l|l} 
European &
\end{tabular} & 1,01 & & 0,92 & \\
\hline & & Visible Minority & 0,92 & & 0,88 & \\
\hline & & Volunteer & 1,09 & & 1,14 & ** \\
\hline & & \begin{tabular}{l|l} 
European \\
\end{tabular} & 1,25 & * & 1,29 & * \\
\hline & & Visible Minority & 0,94 & & 0,87 & \\
\hline & & Recreation org & 1,22 & *** & 1,13 & ** \\
\hline & & \begin{tabular}{l|l} 
European
\end{tabular} & 0,67 & $* \star *$ & 0,92 & \\
\hline & & Visible Minority & 0,94 & & 0,97 & \\
\hline & & $\begin{array}{l}\text { Attend religious } \\
\text { services }\end{array}$ & 1,15 & $* \star \star$ & 1,15 & *** \\
\hline & & \begin{tabular}{l|l} 
European &
\end{tabular} & 1,03 & & 0,96 & \\
\hline & & Visible Minority & 0,97 & & 1,02 & \\
\hline Significance: *: & & evel; ***: 0.01 level & & & & \\
\hline
\end{tabular}

